\title{
ANALISIS DAN PENGEMBANGAN SISTEM INFORMASI PUBLIK DATA POKOK PENDIDIKAN (STUDI KASUS DAPODIK KOTA PADANG)
}

\author{
${ }^{1}$ Nilla Rachmaningrum, ${ }^{2}$ Falahah, ${ }^{3}$ Pramayogi Sanches \\ ${ }^{1}$ Teknik Telekomunikasi, ${ }^{2}$ Teknik Informatika, ${ }^{3}$ Manajemen Informatika \\ ${ }^{1}$ IT Telkom Surabaya, ${ }^{2}$ Universitas Widyatama, ${ }^{3}$ Poltek Telkom \\ IT Telkom Surabaya, Jl. Gayungan PTT No.17-19 Surabaya 60235 \\ 1nilla.rachmaningrum@ittelkom-sby.ac.id, ${ }^{2}$ falahah@widyatama.ac.id, ${ }^{3}$ sanches.pramayogi@gmail.com
}

\begin{abstract}
Abstrak
Sistem informasi publik mengacu pada sistem informasi yang digunakan untuk kepentingan umum yang biasanya menyediakan berbagai tingkat solusi seperti sebagai layanan publik, informasi atau solusi teknologi. Sistem ini biasanya dikembangkan oleh pemerintah untuk memenuhi kebutuhan informasi masyarakat. Secara umum sistem ini memiliki karakteristik yaitu digunakan oleh pihak masyarakat, pemerintah dan pelaku bisnis, menyediakan data-data dengan karakteristik tertentu dan dapat diakses secara cuma-cuma oleh seluruh masyarakat.

Salah satu sistem informasi publik yang pernah dibuat dan digunakan di Indonesia yaitu sistem Data Pokok Pendidikan (Dapodik) yang menyimpan berbagai informasi terkait sekolah, siswa dan guruguru di seluruh Indonesia. Sistem ini cukup populer dan sering diakses oleh masyarakat umum, terutama untuk pencarian NISN (Nomor Induk Siswa Nasional). Namun dalam perkembangannya terjadi perubahan kebijakan di lingkungan Kementrian Pendidikan Nasional sehingga akhirnya sistem ini ditutup dan diganti oleh sistem lain yang sejenis.

Untuk menjembatani adanya kebutuhan sistem informasi sejenis di ruang lingkup yang lebih kecil, dikembangkan sistem Data Pokok Pendidikan untuk tingkatan kabupaten/kota dengan mengambil contoh kasus Dinas Pendidikan Kota Padang. Analisis dan pengembangan sistem ini mengacu pada karakteristik sistem informasi publik dan diharapkan sistem ini dapat menyediakan informasi bagi masyarakat luas mengenai profil sekolah dan informasi lainnya. Pengembangan dan implementasi sistem ini memerlukan dukungan kebijakan, peraturan dan kerjasama antara berbagai pihak terkait.
\end{abstract}

Kata Kunci: Sistem Informasi Publik, analisis, pengembangan, NISN, Dapodik.

\begin{abstract}
Public information systems refer to information systems that are used for public purposes which usually provide various levels of solutions such as public services, information or technological solutions. This system is usually developed by the government to meet people's information needs. In general this system has characteristics that are used by the public, the government and business people, provide data with certain characteristics and can be accessed free of charge by the entire community.
\end{abstract}

One of the public information systems that has been created and used in Indonesia is the Basic Education Data System (Dapodik) which stores various information related to schools, students and teachers throughout Indonesia. This system is quite popular and often accessed by the general public, especially for searches. NISN (National Student Identification Number). But in it's development there has been a change in policy within the Ministry of National Education, so that finally the system was closed and replaced by other similar systems which have not yet completed the data content.

To bridge the need for similar information systems in a smaller scope, a Basic Education Data system was developed for the district / city level by taking the case of the Padang City Education Office. Analysis and development of this system refers to the characteristics of a public information system and it is hoped that this system can provide information for the general public regarding school profiles and other information. The development and implementation of 
this system requires policy support, regulation and cooperation between various related parties.

Keywords: Public Information Systems, analysis, development, NISN, Dapodik.

\section{Pendahuluan}

Transparansi informasi merupakan salah satu kebijakan yang dicanangkan oleh pemerintahan saat ini.Ditandai dengan dibangunnya beberapa aplikasi yang dapat digunakan oleh masyarakat sebagai sumber pencarian informasi dan diintegrasikan pada berbagai sistem e-government yang sudah tersedia.

Kemendiknas, sebagai salah satu stakeholder di bidang pendidikan, berusaha memenuhi kebutuhan akan sistem informasi publik berupa data profil sekolah di seluruh Indonesia. Data ini diharapkan dapat membantu berbagai pihak, mulai dari institusi tingkat daerah seperti pemerintah daerah, dinas pendidikan, atau sekolah-sekolah, maupun masyarakat luas.

Salah satu informasi penting yang terdapat pada sistem ini adalah NISN (nomor induk siswa nasional). Diharapkan, dengan diterapkannya NISN ini maka masyarakat dan pihak terkait dapat menelusuri riwayat pendidikan seorang siswa, meskipun yang bersangkutan berpindah-pindah sekolah atau kota. Sistem ini kemudian dikenal dengan nama Dapodik (Data pokok pendidikan) dan mulai dikembangkan sekitar tahun 2006.

Dalam perkembangannya, sistem Dapodik ini mengalami pasang surut dan mengundang reaksi pro dan kontra. Perubahan kebijakan pada organisasi Kemendiknas mengakibatkan ditutupnya sistem Dapodik pada akhir tahun 2011. Akibatnya, banyak pihak yang merasa kesulitan dalam mendapatkan informasi terkait NISN atau profil sekolah.

Atas dasar kondisi tersebut, dan untuk menyediakan solusi alternatif sampai sistem Dapodik yang baru siap digunakan, maka pada penelitian ini dikembangkan satu prototype sistem Dapodik yang dibuat dengan mengacu pada sistem Dapodik yang lama dan diterapkan untuk studi kasus Dinas Pendidikan Kota Padang. Sistem ini diharapkan dapat dikembangkan menjadi sistem informasi publik yang dapat melayani kebutuhan informasi tentang sekolahsekolah bagi masyrakat.

\section{KAJIAN LITERATUR}

Sistem informasi publik, didefinisikan sebagai "sistem yang dirancang untuk digunakan oleh umum, bukan untuk bidang tertentu atau organisasi tertentu" (Orman, Levent V, 1989). Orman juga mengidentifikasi tiga generasi sistem informasi publik yaitu sistem paket informasi dengan aspek berbagi yang minimal, sistem pengambilan (retrieval) informasi, yang dibuat untuk penyediaan data bukan proses, dan sistem pemrosesan informasi, yang menyediakan aspek berbagi data dan informasi. Orman juga memperkirakan dampak terbesar sistem pengambilan informasi yaitu pada dunia pendidikan.

Sistem informasi publik dibuat untuk menyediakan layanan atau dukungan terhadap proses publik atau proses yang melibatkan masyarakat umum secara luas. Sedangkan sistem informasi "non-publik" hanay digunakan untuk kepentingan internal organisasi tersebut.

Sistem informasi publik biasanya melibatkan tiga aktor utama yaitu (Sundgren, B, 2005):

- Citizen : masyarakan umum, yang berperan sebagai klien.

- Business : perusahaan atau organisasi yang melayani kebutuhan masyarakat

- Government : pemerintah atau institusi yang terkait dengan informasi tersebut, dapat berupa tingkat nasional, regional ataupun local.

Sistem informasi publik dapat menyediakan solusi pada tiga tingkatan (level) berikut yaitu (Sundgren, B, 2005):

- Services : layanan dasar untuk bidang pendidikan, transportasi, industry, pariwisata, dan lain-lain

- Informasi : berupa database publik dan private, perpustakaan digital, situs web, database geografis dan lain-lain.

- Solusi teknis : berupa software aplikasi, sistem operasi, peralatan computer, sistem komunikasi, sistem intranet, extranet dan lain-lain.

Sistem informasi publik mendukung tugas-tugas dan proses yang dilakukan oleh berbagai jenis aktor yang terlibat. Sistem ini memerlukan data dan proses pengolahan informasi ini juga menghasilkan data. Data yang dibutuhkan dan dihasilkan dapat dikategorikan menjadi beberapa jenis, yaitu :

- Data operasional adalah data yang diperlukan untuk berjalannya suatu proses bisnis, yang 
biasanya disediakan oleh partisipan yang terlibat pada proses tersebut, misalnya, pada e-KTP, warga harus memberikan biodata.

- Data prosedur biasanya berupa aturan atau kebijakan pemerintah.

- Data analitik biasanya berupa data statistic, indicator, atau data lain yang diperlukan untuk menunjukan kualitas dari proses yang didukung oleh sistem.

- Metadata biasanya berupa informasi tentang konten, arti, tujuan, kualitas dan ketersediaan datadata yang ada pada sistem

- Data proses atau paradata adalah yang didapat sebagai umpan balik suatu proses. Misalnya, apakah transaksi berhasil atau gagal, siapa yang mengisikan data, dan sebagainya.

- Data arsip atau record, merupakan penyimpaan data mencatat semua data yang terlibat pada proses yang sebenarnya, sebagai akibat interaksi antara tiga aktor pada sistem informasi publik yaitu citizen, government dan business.

Terkait dengan konten sebuah sistem informasi publik, dua hal yang harus dipertimbangkan adalah :

- Sejauh mana transparansi data harus disediakan pada sistem informasi publik?

Tiga isu yang harus dipertimbangkan meliputi publisitas, kerahasiaan (confidentiality) dan privasi.

- Apakah data tersebut dapat diakses secara cumacuma oleh semua orang? Ini dapat difasilitasi dengan infrastruktur internet yang memadai.

\section{AnAlisis dan Perancangan}

\section{III.1 Permasalahan Sistem Dapodik}

Dapodik atau data pokok pendidikan adalah semacam sistem informasi yang dirancang dengan tujuan menyediakan pusat data dan informasi terkait sekolah khususnya tingkatan Dasar, Menengah dan Lanjutan. Awalnya Dapodik merupakan program Depdiknas yang dimulai tahun 2006 sebagai reaksi akibat permasalahan data yaitu (khalidmustafa, 2008):

- Belum dimilikinya data referensi terpusat, teridentifikasi data yang bersifat utama/pokok meliputi: Sekolah, Siswa, Guru dan Kurikulum.
- Ada banyak pulau data yang antara satu dengan lainnya tidak terhubung.

- Metode pengumpulan data yang selama ini menggunakan mekanisme kuisoner manual kurang efektif dan efisien.

- Perlu dimutakhirkan memanfaatkan teknologi infomrasi terkini yaitu sistem pengumpulan data secara online real time.

Sebagai solusi atas permasalahn tersebut, dibuatlah sistem dapodik berbasis web yang dapat diakses melalui alamat http://dapodik.diknas.go.id/.Situs ini beroperasi dengan memanfaatkan infrastruktur Jardiknas dan dioperasikan oleh pihak sekolah sebagai pengentri data. Sejak awal kehadirannya, sistem ini banyak membantu orang tua dan pihak sekolah untuk mencari informasi tentang siswa, khususnya tentang NISN (nomor induk siswa nasional), yang ide dasarnya adalah satu siswa satu nomor induk sehingga dapat ditelusuri rekam jejak siswa tersebut dari pendidikan dasar hingga pendidikan lanjut.

Sistem ini terus berkembang dan disempurnakan dengan penambahan beberapa fitur baru, salah satunya adalah fasilitas pengunduhan data lengkap siswa di satu sekolah dalam format file spreadsheet.Fitur ini akhirnya mengundang kontroversi di dunia maya terkait dengan privasi data siswa. Pada file tersebut dicantumkan data nama dan alamat siswa sehingga dikhawatirkan terjadi penyalahgunaan oleh pihak-pihak yang tidak bertanggung jawab. Atas keberatan ini, maka fitur tersebut akhirnya ditiadakan (2018, http://dapodik.org/sejarah-dapodik)

Hingga akhir tahun 2011, data yang disimpan pada sistem ini cukup lengkap dan akurat karena terus diperbaharui oleh operator tiap sekolah secara berkala setiap tahun ajaran baru. Namun, di awal tahun 2012 terjadi perubahan kebijakan manajerial dan organisasi di lingkungan Depdiknas yang berakibat terbengkalainya sistem ini dan pada akhirnya sistem ini ditutup karena ada peralihan tugas dan tanggung jawab di lingkungan internal Depdiknas (khalidmustafa, 2008). Informasi yang dilansir di situs http://nisn.dapodik.org/ menyatakan bahwa situs tersebut resmi ditutup pada tanggal 1 Januari 2012 dan sistem penggantinya sedang dipersiapkan (http://nisn.dapodik.org/). 
.Hingga tulisan ini dibuat, memang sudah ada sistem pengganti yang dimaksud yaitu http://nisn.data.kemdiknas.go.id yang berfokus pada NISN. Sedangkan data-data lain terkait sekolah seperti identitas sekolah, NPSN (nomor pokok sekolah nasional), jumlah siswa dan sebagainya disimpan pada sistem terpisah yaitu http://infopendataan.dikdas.kemdiknas.go.id/new/inde x.php/

Sistem Dapodik yang baru, meski sudah dapat diakses oleh masyarakat, nampaknya belum dilengkapi dengan data yang memadai. Gambar berikut menampilkan contoh hasil pencarian NISN yang dicobakan pada situs http://nisn.data.kemdiknas.go.id
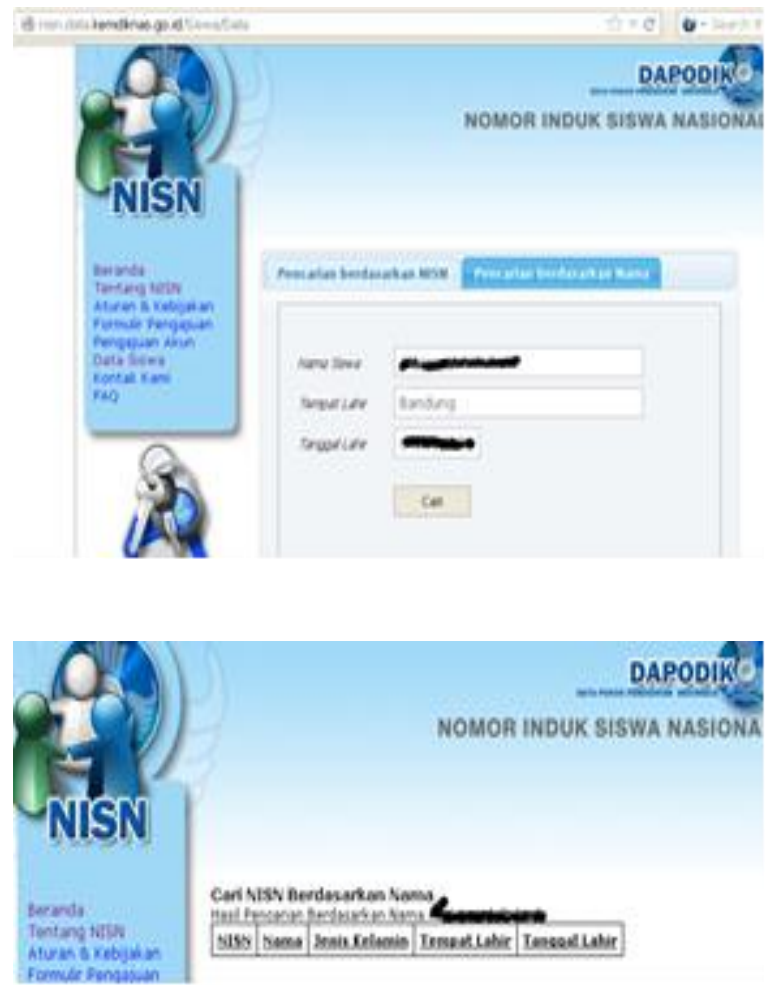

Gambar 1.Tampilan Aplikasi Dapodik yang Baru untuk modul NISN.

(sumber :http://nisn.data.kemdiknas.go.id)

\section{III.2 Pengembangan Sistem Dapodik (Studi Kasus Dinas Pendidikan Kota Padang)}

Berdasarkan kondisi tersebut, dan mengacu pada sistem Dapodik yang sudah pernah beroperasi sebelumnya, maka dikembangkan sebuah sistem Dapodik baru yang dikhususkan untuk wilayah tertentu, sebagai usaha menjembatani kebutuhan sistem dan data sejenis.

Sistem ini dirancang dan dibuat sebelum sistem Dapodik yang baru diluncurkan yaitu diselesaikan sekitar bulan Agustus 2012 dengan studi kasus Dinas Pendidikan Kota Padang. Oleh karena itu, dalam beberapa aspek identifikasi kebutuhan dan rancangan tampilannya, lebih banyak mengacu pada sistem Dapodik sebelumnya dibandingkan dengan yang ada sekarang. Sistem ini bersifat prototype karena setelah dibuat, tidak benar-benar diimplementasikan karena ternyata akhirnya Depdiknas sudah menyediakan sistem baru meskipun masih dalam tahap penyempurnaan.

Kebutuhan sistem Dapodik yang akan dibuat, diturunkan berdasarkan fitur-fitur yang pernah ada pada sistem Dapodik yang pernah ada sebelumnya dan data-data yang sudah tersedia pada situs Dinas Pendidikan Kota Padang (http://www.diknaspadang.org).

Pada sistem yang ada sekarang (Dinas Pendidikan Kota Padang) dicantumkan data sekolah mulai dari SD hingga SLTA seperti pada gambar berikut:

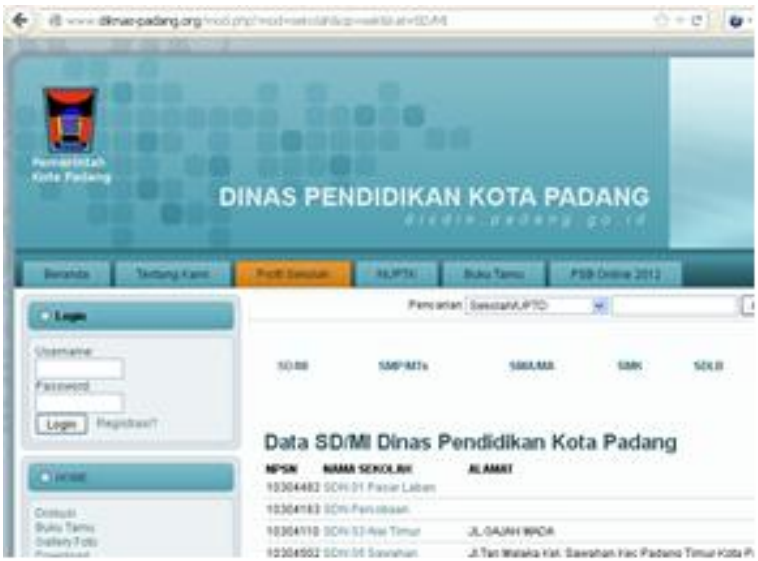

Gambar 2.Tampilan Aplikasi Dapodik Dinas Pendidikan Kota Padang (Existing System). Sumber((http://www.diknas-padang.org).

Informasi detil setiap sekolah dicantumkan seperti pada gambar berikut :

NillaRachmaningrum, Falahah, Pramayogi sanches 


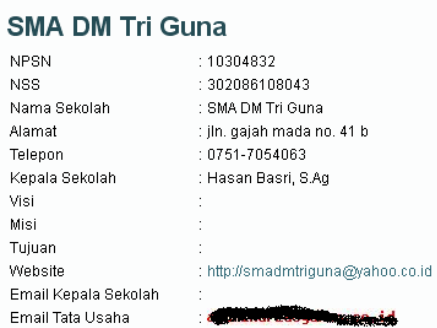

Email Tata Usaha

\begin{tabular}{|c|c|c|}
\hline No & Elemen Data & Deskripsi \\
\hline 1 & Sekolah & $\begin{array}{l}\text { Informasi umum mengenai } \\
\text { sekolah seperti nama sekolah, } \\
\text { alamat, status akreditasi, dan } \\
\text { lain-lain }\end{array}$ \\
\hline 2 & Prodi & $\begin{array}{l}\text { Informasi mengenai program } \\
\text { studi yang disediakan di satu } \\
\text { sekolah (khusus untuk SMK) }\end{array}$ \\
\hline 3 & Siswa & $\begin{array}{l}\text { Informasi siswa yang terdaftar } \\
\text { pada satu sekolah, meliputi } \\
\text { nama, tahun masuk dan NIS }\end{array}$ \\
\hline 4 & Pengurus & $\begin{array}{l}\text { Informasi pengurus sekolah } \\
\text { seperti kepala sekolah, wakil } \\
\text { kepala sekolah dan informasi } \\
\text { lainnya }\end{array}$ \\
\hline 5 & Prestasi & 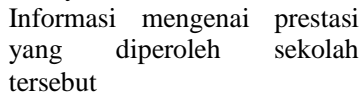 \\
\hline 6 & Guru & $\begin{array}{l}\text { Informasi mengenai guru-guru } \\
\text { yang terdaftar di satu sekolah }\end{array}$ \\
\hline
\end{tabular}

Gambar 4 menunjukkan relasi data yang digunakan pada sistem Dapodik.

Isu penting yang juga diperhatikan pada pengembangan sistem ini adalah isu kerahasiaan dan privasi data mengingat sempat terjadi keluhan masyarakat atas pencantuman data siswa pada situs Dapodik sebelumnya.Oleh karena itu, pada sistem yang dikembangkan ini data-data yang ditampilkan dibatasi pada data-data umum dan tidak memuat data pribadi seperti alamat, tanggal lahir dan sebagainya.

dan dihasilkan oleh sistem ini yaitu data opersional, data analitik, paradata dan data arsip.

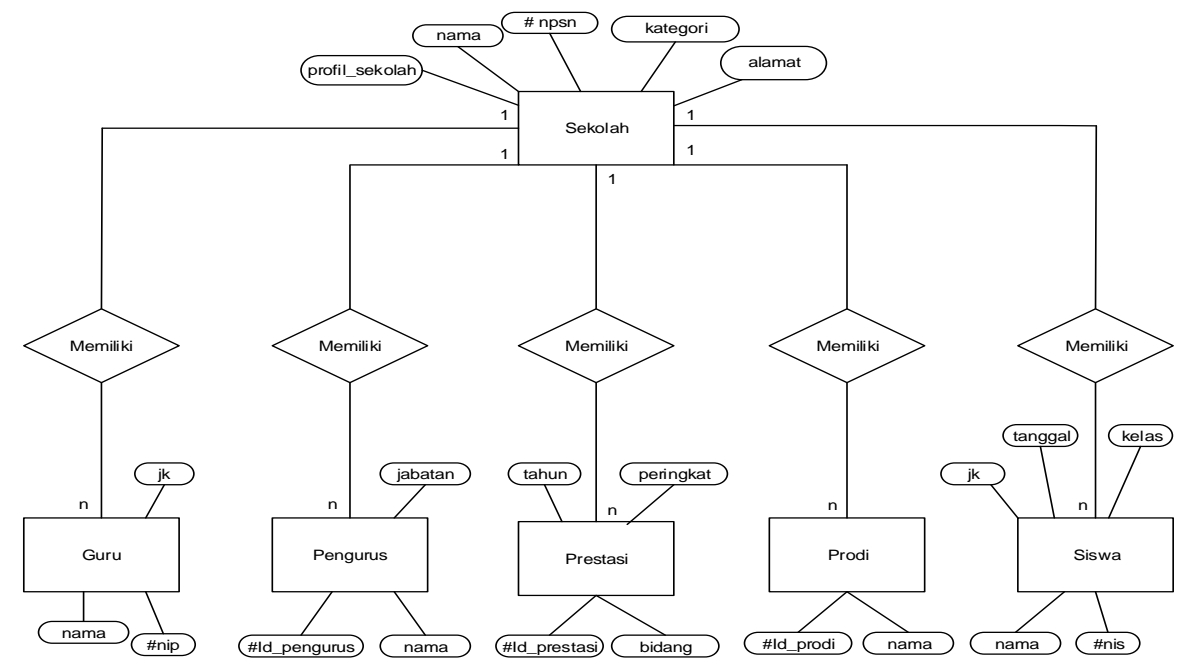

Gambar 4. Relasi Data pada Sistem Dapodik

Tabel 1. Kebutuhan Elemen Data Dapodik

NillaRachmaningrum, Falahah, Pramayogi sanches 
Perbedaan antara sistem Dinas Pendidikan Kota Padang yang sudah ada dengan sistem yang diusulkan ini adalah :

- Ketersediaan elemen informasi yang lebih lengkap yaitu detil informasi tentang sekolah, guru, dan siswa dalam satu tampilan sehingga memudahkan masyarakat untuk melihat profil suatu sekolah

- $\quad$ Adanya rekapitulasi data sekolah di seluruh kota Padang berdasarkan tingkatan (SD, SMP, SMA) dan akreditasi, sehingga memudahkan melihat profil sekolah di kota Padang secara keseluruhan.

Gambar 5, 6, 7 dan 8 menunjukan hasil implementasi pengembangan sistem Dapodik Kota Padang yang dirancang mengacu pada pemenuhan karakteristik sistem informasi publik.

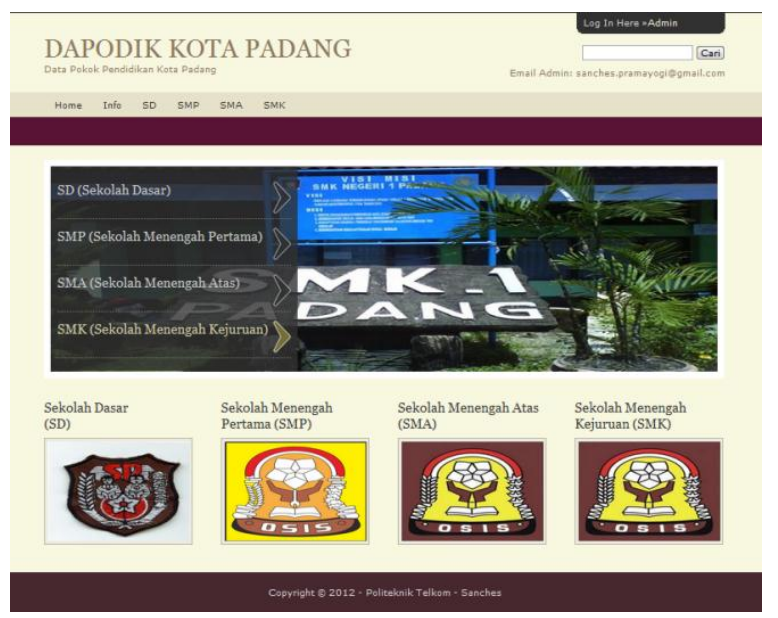

Gambar 5. Tampilan Utama Sistem Dapodik Kota Padang

Data sekolah yang ditampilkan dibatasi pada sekolah dasar, sekolah menengah pertama, sekolah menengah atas dan sekolah kejuruan.

Gambar 6 menampilkan profil lengkap sebuah sekolah yang meliputi profil sekolah, data guru, data pengurus, data prodi dan data siswa serta grafik perkembangan jumlah siswa dari tahun ke tahun.

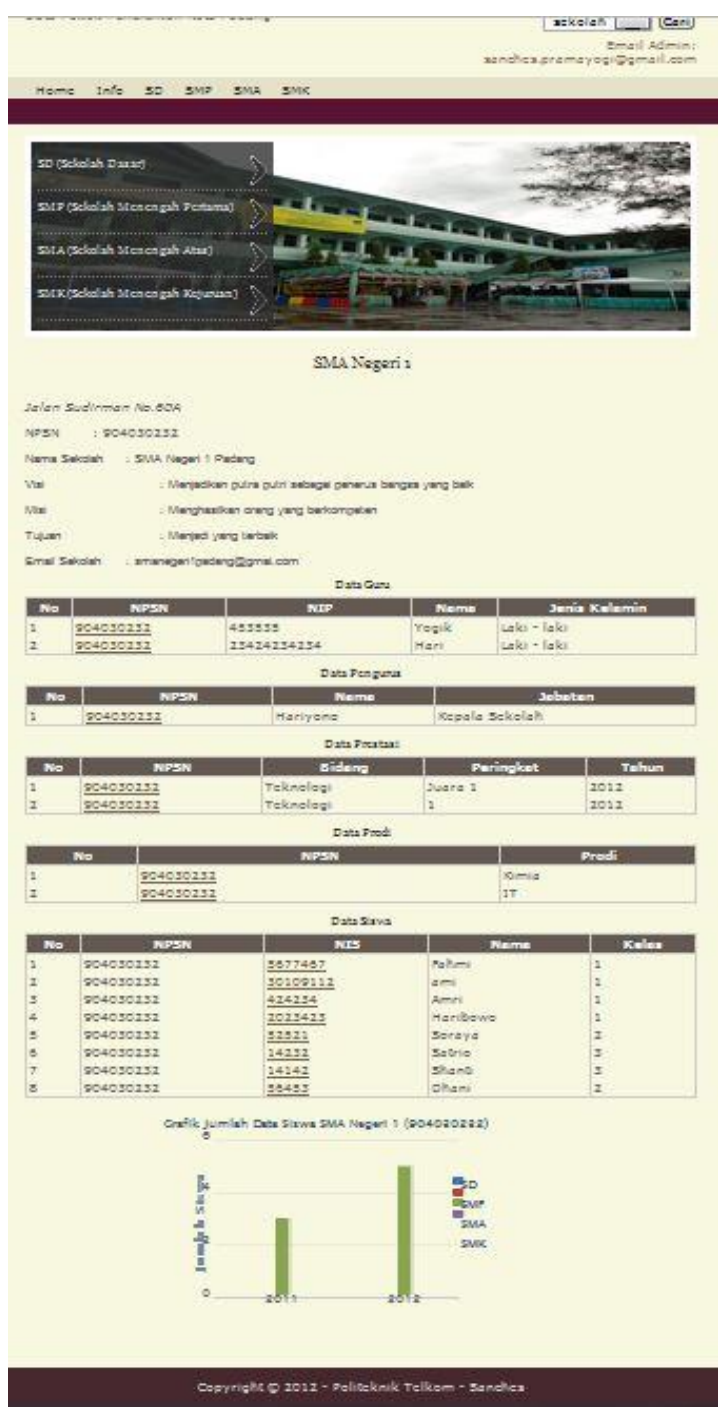

Gambar 6. Tampilan Profil Sekolah pada Sistem Dapodik

Deal Dew Stom

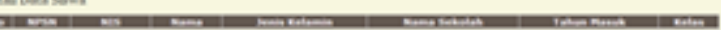

Gambar 7. Tampilan Informasi Detil Siswa

NillaRachmaningrum, Falahah, Pramayogi sanches 


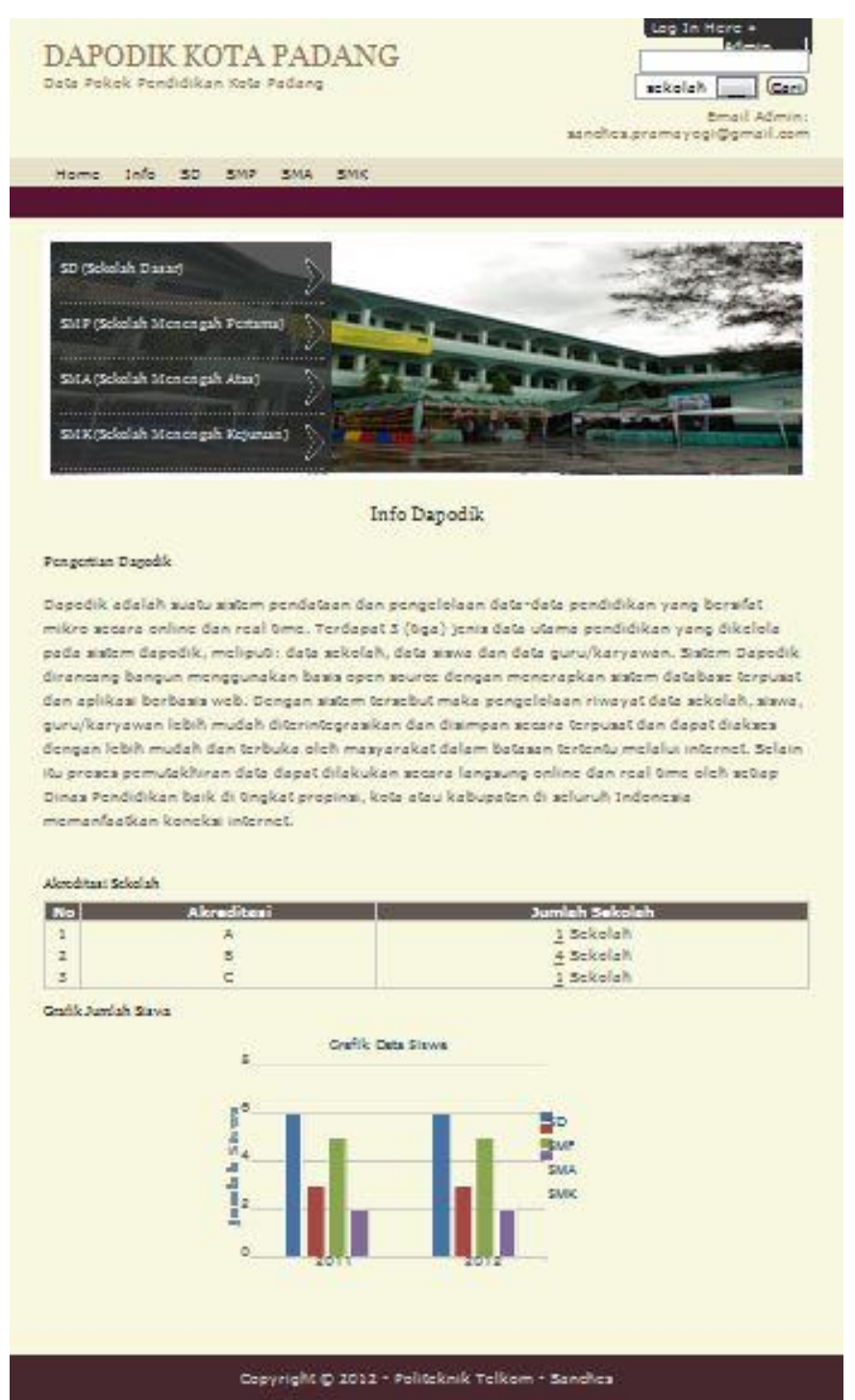

Gambar 8. Tampilan Informasi Rekapitulasi Sekolah berdasarkan tingkat akreditasi

Sejauh mana pemanfaatan sistem ini kelak tergantung pada keinginan pihak terkait untuk melengkapi dan memelihara data.Pelaksanaannya memerlukan dukungan kebijakan, aturan dan kerjasama antara pemerintah dan sekolah terkait.Tanpa kejelasan kebijakan dan aturan, sistem ini tidak mungkin berkembang atau bahkan tidak digunakan seperti halnya sistem Dapodik sebelumnya.

\section{KESIMPULAN DAN SARAN}

Berdasarkan hasil analisis dan pengembangan sistem informasi publik data pokok pendidikan (Dapodik) di atas, dapat ditarik beberapa kesimpulan sebagai berikut :

1. Sistem Dapodik dirancang dan dikembangkan berdasarkan karakteristik sistem informasi public pada umumnya yang mencakup aspek aktor pengguna, sifat layanan dan tipe data yang disediakan.

2. Sistem Dapodik mencakup tiga aspek aktor utama sistem informasi public yaitu pihak government, business dan citizen yang masingmasing diwakili oleh Dinas pendidikan, sekolah dan masyarakat.

3. Data yang disediakan oleh sistem ini termasuk pada kategori data operasional, data analitik, paradata dan data arsip

4. Peluang implementasi dan pemanfaatannya memerlukan dukungan kebijakan dan aturan yang memadai serta kerjasama semua pihak yang terkait terutama pemerinta dan sekolahsekolah.

\section{REFERENSI}

Orman, Levent V. (1989). "Public Information Systems", in Information Society Vol 6 No. $1 / 2$.

Sundgren, B. "What is a Public Information System", International Journal of Public Information System, No.1, 2005, diakses tanggal 10 Maret 2009 dari : http://www.ijpis.net/issues/no1_2005/IJPIS no1_2005_p7.pdf

Khalidamustofa, Dapodik Apakah hanya sebuah program mimpi, 2008 http://www.khalidmustafa.info/2008/01/12/d apodik-apakah-hanya-sebuah-programmimpi.php

http://dapodik.org/post/16956777382/sejarahdapodik 